\title{
Analisis faktor-faktor yang mempengaruhi pendapatan pedagang pengecer daging babi di kota Tomohon
}

\author{
G. Kalele, P.O.V Waleleng*, S.J.K Umboh, N.M. Santa \\ Fakultas Peternakan Universitas Sam Ratulangi Manado 95115 \\ *Korespondensi (corresponding author): pwaleleng@unsrat.ac.,id
}

\begin{abstract}
ABSTRAK
Penelitian ini bertujuan untuk menganalisis faktor-faktor yang mempengaruhi jumlah pendapatan pedagang pengecer daging babi di Kota Tomohon.Lokasi sampel di Pasar Beriman Kota Tomohon, ditentukan menggunakan metode Purposive Sampling, berdasarkan pertimbangan bahwa Pasar Beriman merupakan satu-satunya pasar tradisional terbesar di Kota Tomohon, dan memiliki pedagang pengecer daging babi. Sampel ditentukan menggunakan teknik total quota sampling sebanyak 30 orang yang aktif sebagai pedagang pengecer. Model analisis yang digunakan untuk mengestimasi faktor-faktor yang mempengaruhi pendapatan pedagang pengecer yaitu model persamaan regresi linear berganda dalam bentuk logaritma natural. Hasil penelitian menunjukkan bahwa faktor-faktor yang mempengaruhi pendapatan pedagang pengecer daging babi di Kota Tomohon yaitu jumlah daging babi yang dijual, harga daging babi, modal, tenaga kerjadan lama berusaha.
\end{abstract}

Kata kunci : pendapatan, pedagang pengecer, daging babi

\begin{abstract}
This study aims to analyze the factors that influence the total income of pig meat retailers in Tomohon City. The sample locations in the Beriman Market in Tomohon City, were determined using the purposive sampling method, based on the consideration that Pasar Beriman is the largest traditional market in Tomohon City, and has pig meat retailers. The sample is determined using a total quota sampling technique of 30 people who are active as retailers. The analysis model used to estimate the factors that influence retailers' income is the multiple linear regression equation model in the form of natural logarithms. The results showed that the factors affecting the income of pig meat retailers in Tomohon City were the amount of meat, price, capital, labor and business experience.
\end{abstract}

Keywords: income, retailers, pork 


\section{PENDAHULUAN}

Meningkatkan kesejahteraan umum masyarakat merupakan salah satu tujuan pembangunan nasional berdasarkan UUD 1945. Salah satu indikator kesejahteraan umum suatu masyarakat yaitu terpenuhinya kebutuhan material, sehingga masyarakat dapat hidup layak dan mampu mengembangkan diri. Kebutuhan materia masyarakat dapat terpenuhi apabila material yang dibutuhkan tersedia dan dapat diperoleh dengan mudah. Namun demikian, kebutuhan masyarakat dapat terpenuhi apabila mereka memiliki sejumlah uang untuk dibelanjakan, biasanya disebut pendapatan. Apabila masyarakat tidak memiliki pendapatan, walaupun material sudah tersedia, maka masyarakat pun tidak mampu hidup sejahtera.

Kegiatan pemasaran merupakan satusatunya kegiatan yang mampu menyediakan kebutuhan material masyarakat disuatu daerah. Tanpa kegiatan pemasaran, suatu barang yang diproduksi oleh produsen tidak dapat sampai ke tangan konsumen. Salah satu pihak yang terlibat dalam kegiatan pemasaran yaitu pedagang. Dalam kegiatan pemasaran, pedagang akan terus ada dan bekerja apabila pedagang tersebut memperoleh pendapatan dari usaha yang dijalankan. Terdapat faktor-faktor yang mempengaruhi pendapatan pedagang pengecer di pasar yaitu modal, lokasi berdagang, jumlah tenaga kerja, lama berusaha dan kondisi tempat berdagang (Wahyono, 2017; Butarbutar et al., 2014; Firdausa et al., 2013; Chintya et al., 2013; Ma'arif, 2013).

Kota Tomohon memiliki Pasar Beriman yang merupakan satu-satunya pasar tradisional dan terbesar sejak tahun 1979 dan berlokasi di dekat Terminal Beriman di Kelurahan Paslaten I. Pasar ini menjual berbagai macam jenis daging antara lain: daging sapi, babi, anjing, tikus pohon, kelelawar dan ayam. Daging yang dijual sangat segar, karena baru di sembelih di rumah potong hewan di pasar itu. Selain itu, pasar Tomohon juga menjual berbagai jenis ikan laut dan ikan air tawar yang dipasok dari daerah Bitung, Tanawangko dan Tondano. Karena Pasar Tomohon lebih lengkap, sehingga banyak pedagang lain yang khusus datang berbelanja di Pasar Tomohon dalam jumlah besar.

Salah satu sumber protein hewani bagi masyarakat yang dijual di Pasar Beriman Tomohon yaitu daging babi. Berdasarkan hasil pra survey pada bulan Desember 2019 diketahui bahwa terdapat 50 orang pedagang khusus menjual daging babi. Terdapat pedagang yang juga sebagai pedagang pengumpul sekaligus tukang potong babi, serta ada juga pedagang eceran daging babi. Semua pedagang memiliki kios yang tetap untuk mendagangkan daging babi dan berada di lokasi khusus terpisah dengan daging sapi dan daging ayam.

Pedagang pengecer daging babi di Pasar Beriman Tomohon, sering mengalami pasang surut terhadap jumlah pendapatan yang diterima. Meskipun pada suatu waktu pedagang menjual daging babi dalam jumlah yang sama, namun jumlah pendapatan yang diterima berbeda, yang antara lain disebabkan oleh harga daging yang bervariasi. Sejak bulan Maret, Kota Tomohon mengalami wabah Pandemic Covid-19 yang menyebabkan beberapa hal antara lain, berkurangnya jumlah konsumen yang membeli daging babi, menyebabkan harga daging babi turun dari Rp60.000 menjadi Rp30.000. Harga daging babi sebelum adanya Pandemic Covid-19 berkisar Rp60.000 sampai dengan Rp65.000 per kilogram (Osak et al.,2020). Perlu diketahui lebih lanjut tentang hubungan antara penurunan harga jual daging babi dengan pendapatan yang diterima pedagang pengecer. Selain faktor harga daging babi, terdapat faktor-faktor lain yang juga berpengaruh terhadap pendapatan pedagang pengecer daging babi di Pasar Beriman Tomohon. Penelitian tentang faktor-faktor yang mempengaruhi pendapatan pedagang pengecer daging babi di Kota Tomohon 
berbeda dengan beberapa penelitian sebelumnya (Wahyono, 2017; Firdausa et al., 2013; Chintya et al., 2013; Ma'arif, 2013; Osak et al., 2020). Perbedaan utama pada waktu pelaksanaan penelitian dengan adanya penurunan harga jual akibat pandemi Covid-19 dan penggunaan variabel jumlah daging babi yang dijual yang belum pernah digunakan oleh peneliti sebelumnya.

Berdasarkan penjelasan diatas, maka rumusan masalah yaitu faktor apa saja yang berpengaruh terhadap jumlah pendapatan pedagang pengecer daging babi. Dengan demikian, penelitian ini bertujuan untuk menganalisis faktor-faktor yang mempengaruhi jumlah pendapatan pedagang pengecer daging babi di Kota Tomohon.

\section{METODE PENELITIAN}

\section{Tempat dan waktu penelitian}

Lokasi penelitian dilaksanakan di Pasar Tradisional Beriman Kota Tomohon selama tanggal 16-30 September 2020.

\section{Jenis dan sumber data}

Data yang digunakan dalam penelitian ini yaitu data primer dan data sekunder. Data primer merupakan hasil pengamatan dan hasil wawancara terhadap pedagang pengecer daging babi sebagai responden. Data sekunder berupa data dari Badan Pusat Statistik serta jurnal yang berkaitan dengan penelitian.

\section{Metode penentuan sampel}

Penentuan lokasi sampel di Pasar Beriman Kota Tomohon menggunakan metode Purposive Sampling (Silalahi, 2015), berdasarkan pertimbangan bahwa Pasar Beriman merupakan satu-satunya pasar tradisional terbesar di Kota Tomohon, dan memiliki pedagang pengecer daging babi. Jumlah populasi pedagang pengecer daging babi berjumlah 30 orang, sehingga sampel dalam penelitian ini ditentukan menggunakan teknik total quota sampling sebanyak 30 orang yang aktif sebagai pedagang pengecer.

\section{Model analisis}

Tujuan penelitian ini yaitu untuk menganalisis faktor-faktor yang mempengaruhi jumlah pendapatan pengecer daging babi, menggunakan persamaan regresi liner berganda model logaritma natural berikut.

$$
\begin{aligned}
\ln \mathrm{Y}= & \mathrm{b}_{0}+\mathrm{b}_{1} \ln \mathrm{X}_{1}+\mathrm{b}_{2} \ln \mathrm{X}_{2}+\mathrm{b}_{3} \ln \mathrm{X}_{3}+\mathrm{b}_{4} \ln \mathrm{X}_{4}+ \\
& \mathrm{b}_{5} \ln \mathrm{X}_{5}+\mathrm{e}
\end{aligned}
$$

\section{Keterangan:}

$$
\begin{array}{ll}
\mathrm{Y} & =\text { pendapatan (rupiah/tahun) } \\
\mathrm{b}_{0} & =\text { konstanta } \\
\mathrm{X}_{1} & =\text { jumlah daging }(\mathrm{kg} / \mathrm{tahun}) \\
\mathrm{X}_{2} & =\text { harga (rupiah/kg) } \\
\mathrm{X}_{3} & =\text { modal (rupiah/tahun) } \\
\mathrm{X}_{4} & =\text { tenaga kerja (HOK/tahun) } \\
\mathrm{X}_{5} & =\text { lama berusaha (tahun) } \\
\mathrm{e} & =\text { error }
\end{array}
$$

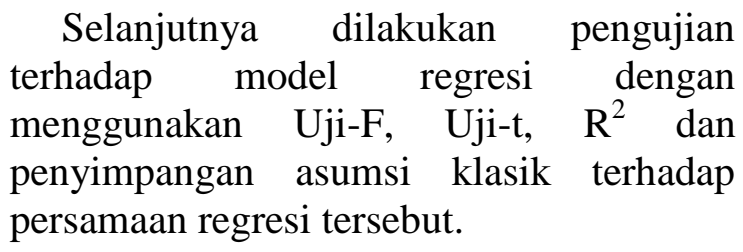

\section{HASIL DAN PEMBAHASAN}

\section{Karakteristik pedagang pengecer}

Umur pedagang pengecer daging babi di Pasar Beriman Tomohon, bervariasi pada umur 20-60 tahun, dengan jumlah pedagang yang berumur 42-52 tahun terdapat $53,33 \%$ dari total pedagang. Keadaan tersebut sejalan dengan Suprapti (2018), bahwa umur pedagang bervariasi antara 25-80 tahun. Pedagang pengecer daging babi termasuk tenaga kerja kategori umur produktif sesuai dengan Undangundang Nomor 13 Tahun 2003, sehingga pedagang memiliki tenaga yang dapat bekerja optimal.

Tingkat pendidikan pedagang daging babi di Pasar Beriman Tomohon, bervariasi antara Tamat SMP dan Perguruan Tinggi, dengan jumlah pedagang yang memiliki tingkat pendidikan Tamat SMP terdapat 76,67\% 
dari total pedagang. Tingkat pendidikan pedagang berhubungan dengan keterampilan berdagang (Wahyono, 2017). Keterampilan berdagang merupakan modal bagi pedagang untuk mendapatkan pelanggan.

Lama usaha pedagang babi di Pasar Beriman Tomohon, bervariasi antara 7-20 tahun waktu yang digunakan sebagai pedagang babi, dengan $86,67 \%$ pedagang memiliki pengalaman berdagang yaitu 1120 tahun. Semakin lama seseorang menekuni usahanya, maka semakin tinggi keterampilan dan keahliannya dalam berdagang (Suriadi, 2018). Pedagang dengan pengalaman lebih dari 10 tahun memiliki pelanggan tetap yaitu rumah makan yang setiap hari membutuhkan daging babi untuk dijual. Setiap hari, pedagang menyediakan daging babi sesuai pesanan.

Jumlah waktu yang dialokasikan pedagang untuk berdagang daging babi bervariasi pada 8-16 jam/minggu. Hasil wawancara mendapati bahwa terdapat pedagang yang berjualan di pasar sebanyak 3-4 kali per minggu dengan rata-rata waktu kerja 6-8 jam/hari.

Pedagang pengecer menghabiskan waktu untuk bekerja selama 360-480 menit/hari atau 6-8 jam/hari, untuk kegiatan membersihkan meja tempat jualan (yaitu sebelum dan sesuai berjualan), membersihkan peralatan (pisau dan atau parang untuk memotong daging, timbangan), menyiapkan daging babi untuk dijual (jika pedagang merupakan tukang potong, maka aktifitas yang dilakukan yaitu membeli, memotong dan membersihkan ternak babi; pedagang lainnya yaitu membeli daging babi dari tukang potong), menyiapkan bahan berupa plastik (untuk membungkus daging babi) dan menjual daging babi.

Terdapat 10 orang pedagang pengecer yang bekerja sebagai tukang potong babi. Aktivitasnya dimulai sejak satu hari sebelumnya yaitu mencari ternak babi yang akan dipotong dan dijual pada hari berikutnya. Aktivitas tersebut di mulai sekitar pukul 14.00, yaitu setelah pedagang menyelesaikan pekerjaan berdagang daging babi di pasar. Pedagang membeli ternak babi di lokasi kandang milik peternak dengan harga Rp2.500.000/ekor atau sekitar Rp25.000/kg berat hidup dengan rata-rata bobot badan 95-100 $\mathrm{kg}$ /ekor. Harga tersebut diperoleh dengan menaksir berdasarkan penampilan badan ternak (Afirin et al., 2016). Kegiatan selanjutnya yaitu pedagang membawa ternak tersebut ke kandang ternak babi miliknya, dilanjutkan dengan memotong ternak babi pada pukul 03.30 pagi, kemudian membawa ke pasar untuk dijual. Pedagang pengecer lainnya, menunggu pedagang yang sekaligus tukang potong babi, selanjutnya membeli daging babi yang sudah siap dijual.

Tabel 1. Hasil Analisis Regresi Faktor-Faktor yang Mempengaruhi Pendapatan Pedagang Pengecer Daging Babi

\begin{tabular}{lcr}
\hline \multicolumn{1}{c}{ Variabel } & TH & Koefisien \\
\hline Jumlah Daging & + & $0,317^{* * * *}$ \\
Harga & + & $0,887^{* * * *}$ \\
Modal & + & $0,415^{* * *}$ \\
Tenaga Kerja & + & 0,095 \\
Lama berusaha & + & $0,075^{* *}$ \\
\hline R-squared & & 0,98 \\
F-hitung & & 276,248 \\
DW & & 1,927 \\
\hline
\end{tabular}

Keterangan : $\left.{ }^{* * *}\right)$ signifikan pada $\left.\alpha=1 \%, * *\right)$ signifikan pada $\alpha=5 \%$, 


\section{Faktor-faktor yang mempengaruhi pendapatan pedagang}

Hasil pengujian terhadap faktor-faktor yang mempengaruhi pendapatan pedagang pengecer daging babi digunakan analisis linier berganda, dimana variabel bebas (independent) yakni jumlah daging $\left(\mathrm{X}_{1}\right)$, harga $\left(\mathrm{X}_{2}\right)$, modal $\left(\mathrm{X}_{3}\right)$, tenaga kerja $\left(\mathrm{X}_{4}\right)$, dan lama berusaha $\left(\mathrm{X}_{5}\right)$ terhadap variabel terikat (dependent) pendapatan (Y), sebesar 98,2\%, dan selebihnya yaitu sebesar $1,8 \%$ dijelaskan oleh variasi variabel lain di luar model atau variabel yang tidak diteliti. Hasil perhitungan terhadap nilai F-hitung yaitu 276,24 menunjukkan angka lebih besar dari nilai F-tabel artinya variabel jumlah daging $\left(\mathrm{X}_{1}\right)$, harga $\left(\mathrm{X}_{2}\right)$, modal $\left(\mathrm{X}_{3}\right)$, tenaga kerja $\left(\mathrm{X}_{4}\right)$, dan lama berusaha $\left(\mathrm{X}_{5}\right)$ berpengaruh nyata terhadap variabel pendapatan (Y).

Langkah selanjutnya yaitu dilakukan pengujian terhadap penyimpangan asumsi klasik, yang bertujuan untuk untuk memastikan persamaan regresi yang dibangun memiliki hasil estimasi yang tepat, estimasinya tidak bias dan konsisten. Pengujian adanya penyimpangan asumsi klasik multikolinearitas diketahui dengan membandingkan nilai $\mathrm{R}^{2}$ yang diperoleh melalui hasil regresi dengan jumlah variabel bebas yang signifikan dalam model. Berdasarkan informasi pada Tabel 1 diketahui bahwa nilai $\mathrm{R}^{2}$ yaitu 0,982 dengan jumlah variabel bebas yang disignifikan yaitu terdapat 4 variabel yang signifikan dari total 5 variabel bebas yang digunakan dalam model. Dengan demikian model bebas dari penyimpangan asumsi klasik multikolinearitas. Pengujian adanya penyimpangan asumsi klasik selanjutnya yaitu autokorelasi diketahui dengan membandingkan nilai Durbin Watson (DW) yang diperoleh melalui hasil analisis regresi. Berdasarkan hasil analisis (lampiran 1) diketahui bahwa nilai DW model yaitu 1,927. Langkah selanjutnya yaitu melakukan perbandingan nilai DW dengan nilai DU, DL, 4-DL dan 4-DU.. Berdasarkan hasil perhitungan diketahui bahwa nilai DW yaitu 1,80 berada di dengan hasil analisis regresi dijelaskan pada tabel 1.

Berdasarkan hasil regresi pada tabel 1 diketahui model persamaan yang dibangun termasuk model yang baik berdasarkan nilai $\mathrm{R}^{2}$ hasil regresi yaitu 0,98 , artinya variasi variabel jumlah daging $\left(\mathrm{X}_{1}\right)$, harga $\left(\mathrm{X}_{2}\right)$, modal $\left(\mathrm{X}_{3}\right)$, tenaga kerja $\left(\mathrm{X}_{4}\right)$, dan lama berusaha $\left(\mathrm{X}_{5}\right)$, dapat menjelaskan variasi variabel antara nilai DU dan DL sehingga diputuskan bahwa penyimpangan asumsi klasik autokorelasi tidak terjadi. Dengan demikian model yang dibangun merupakan model yang tepat, tidak bias dan konsisten.

Faktor-faktor yang mempengaruhi pendapatan pengecer daging babi di Pasar Beriman Tomohon, dijelaskan sebagai berikut.

\section{Jumlah Daging}

Variabel jumlah daging berpengaruh sangat nyata terhadap pendapatan $(\mathrm{P}<0,001)$ dengan koefisien regresi yaitu 0,317 . Koefisien regresi variabel jumlah daging bernilai positif dan sesuai dengan tanda harapan, artinya setiap pertambahan jumlah daging yang dijual sebesar 1 persen, maka pedagang akan menerima peningkatan pendapatan sebesar $0,31 \%$. Keadaan tersebut sejalan dengan hasil penelitian Sutriyono dan Setianto (2019) bahwa jumlah daging yang dijual berpengaruh positif terhadap jumlah pendapatan pedagang pengecer.

Berdasarkan hasil penelitian diketahui bahwa pedagang pengecer menjual daging babi sebanyak 3-4 kali per minggu dengan jumlah daging yang dijual sebanyak 50$100 \mathrm{~kg} / \mathrm{hari}$ dan berkisar 200-400 $\mathrm{kg} / \mathrm{minggu}$. Osak et al., 2020 mendapati bahwa jumlah penjualan daging babi di pasar Tradisional di Kota Manado sebanyak $567 \mathrm{~kg} /$ minggu. Berdasarkan hasil penelitian terbukti bahwa jumlah penjualan daging babi di masa pandemi Covid-19 terjadi penurunan.

Banyaknya daging babi yang dijual bergantung pada jumlah konsumen dan jumlah daging yang dibeli. Pedagang yang 
menjual daging paling banyak, umumnya sudah memiliki konsumen tetap atau disebut langganan. Biasanya konsumen tersebut merupakan pemilik usaha rumah makan dengan menu yang ditawarkan yaitu daging babi seperti sate dan ragey.

\section{Harga}

Variabel harga berpengaruh sangat nyata terhadap pendapatan $(\mathrm{P}<0,001)$ dengan koefisien regresi yaitu 0,887 . Koefisien regresi variabel harga bernilai positif dan sesuai dengan tanda harapan, artinya setiap pertambahan harga daging babi yang dijual sebesar 1 persen,maka pedagang akan menerima peningkatan pendapatan sebesar 0,88\%. Keadaan tersebut sejalan dengan hasil penelitian Sutriyono dan Setianto (2019) bahwa harga barang itu sendiri berpengaruh positif terhadap jumlah pendapatan pedagang pengecer.

Berdasarkan hasil penelitian diketahui bahwa pedagang pengecer menjual daging babi dengan harga Rp36.000-Rp41.000 per kilogram daging. Harga daging babi sebelum adanya pandemi Covid 19 berkisar antara Rp60.000 sampai dengan Rp65.000 per kilogram daging (Osak et al.,2020).

Harga daging babi menyesuaikan dengan harga pasar dan keadaan atau situasi keadaan masyarakat. Sebagai contoh pada hari-hari raya keagamaan, harga daging babi akan meningkat sampai Rp44.000/kg sedangkan pada saat sekarang ini di masa pandemi, harga daging babi mencapai Rp36.000/kg.

\section{Modal}

Variabel modal berpengaruh sangat nyata terhadap pendapatan $(\mathrm{P}<0,001)$ dengan koefisien regresi yaitu 0,415. Koefisien regresi variabel modal bernilai positif dan sesuai dengan tanda harapan, artinya setiap pertambahan modal sebesar 1 persen, maka pedagang akan menerima peningkatan pendapatan sebesar $0,41 \%$. Keadaan tersebut sejalan dengan hasil penelitian Yuniarty (2019), Hanum (2017) dan Ma'arif (2013) bahwa modal berpengaruh positif terhadap pendapatan pedagang.

Berdasarkan hasil penelitian diketahui bahwa modal digunakan oleh pedagang pengecer untuk membeli ternak atau daging babi, membeli peralatan (pisau, parang, timbangan, talenan kayu), dan menyewa tempat berjualan. Pedagang pengecer membayar sewa tempat berdagang kepada PD Pasar Beriman Tomohon sebanyak Rp300.000 sebagai uang pangkal, disetor pada saat mendaftarkan diri sebagai anggota pedagang di pasar. Selain itu, pedagang pengecer membayar uang harian sebanyak Rp2000 untuk setiap kali berjualan. Selanjutnya, pedagang pengecer membutuhkan modal sebanyak Rp2.200.000 sampai dengan Rp6.000.000 yang dikeluarkan pada setiap waktu pedagang akan menjual di pasar, digunakan untuk membeli ternak babi untuk dipotong dan dijual.

\section{Lama berusaha}

Variabel lama berusaha berpengaruh nyata terhadap pendapatan $(\mathrm{P}<0,05)$ dengan koefisien regresi yaitu 0,075 . Koefisien regresi variabel lama berusaha bernilai positif dan sesuai dengan tanda harapan, artinya setiap pertambahan lama berusaha sebesar 1 persen, maka pedagang akan menerima peningkatan pendapatan sebesar $0,07 \%$. Keadaan tersebut sejalan dengan hasil penelitian Putera dan Dewi (2018), Hanum (2017), dan Artaman (2015), bahwa lama usaha berpengaruh positif terhadap jumlah pendapatan pedagang pengecer.

Berdasarkan hasil penelitian diketahui bahwa lama berusaha pedagang pengecer yaitu 7-21 tahun. Lamanya waktu pedagang berjualan di pasar, sangat menentukan jumlah daging babi yang dijual. Pedagang pengecer yang sudah lama menjual daging babi, biasanya memiliki konsumen tetap (biasa disebut langganan). Konsumen menghubungi pedagang sehari sebelumnya untuk 
melakukan pemesanan jumlah daging yang akan dibeli, sehingga pedagang sudah mengetahui jumlah minimal daging yang akan disediakan. Pedagang pengecer dengan keanggotaan yang baru di pasar, umumnya belum memiliki konsumen tetap.

\section{KESIMPULAN}

Faktor-faktor yang mempengaruhi pendapatan pedagang pengecer daging babi di Kota Tomohon yaitu jumlah daging babi, harga daging babi, modal, lama berusaha dan tenaga kerja.

\section{DAFTAR PUSTAKA}

Arifin, R., E. Rianto dan I. Susilowati. 2016. Analisis keuntungan jagal sapi di rph kota semarang berdasarkan saluran pemasaran dan system penjualan. Jurnal Kesejahteraan Sosial. 3(2)94-103

Artaman, D.M.A. (2015). Analisis FaktorFaktor yang Mempengaruhi Pendapatan Pedagang Pasar Seni Sukawati di Kabupaten Gianyar. Tesis. Program Magister Program Studi Ilmu Ekonomi Program Pascasarjana. Universitas Udayana Denpasar.

BPS Kota Tomohon. 2020. Kota Tomohon Dalam Angka 2020. ISSN : 2654.98.24.

https://tomohonkota.bps.go.id/

Butarbutar, N., B. Rorimpandey, R.A.J. Legrans, dan I.D.R. Lumenta, 2014. Analisis keuntungan pedagang pengecer daging sapi di pasar tradisional Kota Manado. Zootek 34 (1):48-61.

Chintya, W. Ajeng dan I. B. Darsan. 2013. Analisis pendapatan pedagang di pasar Jimbaran Kelurahan Jimbaran. Jurnal Ekonomi Pembangunan Udayana. 2(6):277-313.

Firdausa, R. Artistyan dan F. Arianti. 2013. Pengaruh modal awal, lama usaha dan jam kerja terhadap pendapatan pedagang kios di pasar bintoro demak. Jurnal Ekonomi Diponegoro. 2(1):1-6.

Hanum, N. 2017. Analisis faktor-faktor yang mempengaruhi pendapatan pedagang kaki lima di kota kuala simpang. Jurnal Samudra Ekonomika. 1(1)72-86.

Ma'arif, S. 2013. Analisis faktor-faktor yang mempengaruhi pendapatan pedagang pasar bandarjo unggaran kabupaten semarang. Economics Development Analysis Journal. 2(2):1-8.

Osak, R.E.M.F., V.V.J. Panelewen, T. D.F. Lumy dan F.N.S Oroh. 2020. Anallisis keuntungan pedagang daging babi berdasarkan preferensi konsumen di pasar tradisional kota manado. Zootec. 40(1):1-11.

Putra, K.G.C.A dan M.H.U. Dewi. 2018. Analisis faktor-faktor yang mempengaruhi pendapatan pedagang di pasar badung kota denpasar : studi sebelum dan sesudah di relokasi. EJurnal Ekonomi Pembangunan. 7(6):1140-1167.

Silalahi, U. 2015. Metode Penelitian Sosial Kuantitatif. Refika Aditama. Bandung

Suprapti, E. 2018. Pengaruh modal, umur, jam kerja dan pendidikan terhadap pendapatan pedagang perempuan pasar Baringan Bantul. Jurnal Pendidikan dan Ekonomi. 7(2):175183.

Sutriyono, J dan Setianto. 2019. Pendapatan pedagang ayam kampung pada pasar tradisional di kota bengkulu. Jurnal Sain Peternakan Indonesia. 14(4): 440447

Wahyono, B. 2017. Analisis faktor-faktor yang mempengaruhi pendapatan pedagang di pasar bantul kabupaten bantul. Jurnal Pendidikan Ekonomi. 6(4):388-399.

Winarno, W. W. 2015. Analisis Ekonometrika dan Statistika dengan Eviews, Edisi empat. Yogyakarta: UPP STIM YKPN 
Yuniarti, P. 2019. Analisis faktor-faktor yang mempengaruhi pendapatan pedagang di pasar tradisional Cinere Depok. Widya Cipta. 3(1):165-170. 